Andrews, J. R. 1969: A kimberlite dyke in the Nigerdlikasik area, Frederikshåb district. Rapp. Grønlands geol. Unders. 19, 35-37.

Bridgwater, D. \& Gormsen, K. 1969: Geological reconnaissance of the Precambrian rocks of South-East Greenland. Rapp. Grenlands geol. Unders. 19, 43-50.

Evans, C. R. \& Tarney, J. 1964: Isotopic ages of Assynt dykes. Nature, Lond. 204, 638-641.

Jepsen, H. F. 1969: Preliminary report on the stratigraphy of the Precambrian and Eocambrian sediments in the Jørgen Brønlund Fjord - Midsommersø area, southern Peary Land. Rapp. Gronlands geol. Unders. 19, 11-14.

Larsen, O. 1969: K/Ar age determinations. Rapp. Grønlands geol. Unders. 19, 62-67.

Larsen, O. \& Møller, J. 1968: K/Ar age determinations from western Greenland I. Reconnaissance programme. Rapp. Grenlands geol. Unders. 15, 82-86.

Leech, G. B., Lowdon, J. A., Stockwell, C. H. \& Wanless, R. K. 1963: Age determinations and geological studies (including isotopic ages - Report 4). Pap. geol. Surv. Can. 63-17.

Upton, B. G. J. 1965: The petrology of a camptonite sill in South Greenland. Bull. Gronlands geol. Unders. 50 (also Meddr Gronland 169, 11).

Walton. B. 1966: Carbonatite-lamprophyre dykes of Mesozoic age. Rapp. Gronlands geol. Unders. 11, 37-38.

Watt, W. S. 1969: The coast-parallel dike swarm of southwest Greenland in relation to the opening of the Labrador Sea. Can J. Earth Sci. 6, 1320-1321.

Windley, B. F. in press: Primary quartz ferro-dolerite/garnet amphibolite dykes in the Sukkertoppen region of West Greenland. Geol. J.

\title{
K/AR AGE DETERMINATIONS ON DOLERITES FROM SOUTHERN PEARY LAND
}

\section{N. Henriksen and H. F. Jepsen}

Whole rock $\mathrm{K} / \mathrm{Ar}$ age determinations have been undertaken on two Precambrian discordant sills and one post Lower Cambrian dyke from the Jørgen Brønlund Fjord - Midsommersø area. The rocks, which were collected by H. F. Jepsen, were chosen for age determination to obtain a minimum age of the pre-tillitic sandstones in southern Peary Land and from this to get an indication of the age of the youngest sedimentation in the Carolinidian geosyncline (Haller, 1961).

The two Precambrian discordant sills are representative of a swarm of basic intrusions found throughout a series of unfolded sandstones, which are the oldest exposed rocks in the region. An erosional unconformity separates these sandstones and sills from the unfolded Eocambrian sequence above; at the base of the latter occurs a tillite horizon (Jepsen, 1969). The Eocambrian strata are succeeded by the Lower Cambrian Brønlund Fjord Dolomite (Troelsen 1949, 1956), which is cut by a group of doleritic dykes represented by the third of the dated rocks. 
Pre-tillite discordant sills in the unfolded sandstones

$982 \pm 19 \mathrm{~m}$. y. (mean of $3 \mathrm{~K} /$ Ar determinations)

$988 \pm 20 \mathrm{~m}$. y. $\left({ }^{40} \mathrm{Ar} /{ }^{39} \mathrm{Ar}\right.$ spectrum analysis)

GGU 114091. Fine-grained quartz dolerite, representing the youngest of two intrusive units in a $100 \mathrm{~m}$ thick complex sill, from south of Øvre Midsommers $ø .82^{\circ} 12^{\prime} \mathrm{N}$, $34^{\circ} 06^{\prime} \mathrm{W}$.

Mineralogy: Completely saussuritised plagioclase, uralitised pigeonite, fresh augite, opaque $\mathrm{Fe}-\mathrm{Ti}$ oxides and a chloritic cryptocrystalline quartzo-feldspathic intergrowth.

The spectrum analysis showed that no loosely-bound excess argon was incorporated in the rock. The results are therefore interpreted as giving a minimum age for the intrusion of the sill.

$$
799 \pm 68 \mathrm{~m} . \mathrm{y} \text {. (mean of } 3 \mathrm{~K} / \mathrm{Ar} \text { determinations) }
$$

GGU 114156. Medium-grained porphyritic quartz dolerite from the central part of an at least $65 \mathrm{~m}$ thick sill which is cut by a younger $30 \mathrm{~m}$ thick sheet; southern shore of Nedre Midsommersø. $82^{\circ} 15^{\prime} \mathrm{N}, 33^{\circ} 28^{\prime} \mathrm{W}$.

Mineralogy: Completely saussuritised plagioclase, fresh augite, some uralitised pigeonite, opaque $\mathrm{Fe}-\mathrm{Ti}$ oxides, serpentinised bronzite phenocrysts mantled with clinopyroxenes and a chloritic cryptocrystalline quartzo-feldspathic intergrowth.

The result obtained from the badly altered rock must be regarded with some reservation. The rock could have been intruded at about same time as the sill represented by sample 114091, and later subjected to a further weak alteration which caused a loss of argon. An alternative interpretation is that the rock was intruded after the sill represented by sample 114091 at a time represented by the result of the age determination; this latter explanation is less likely than the former, unless the Precambrian sandstones contain several widely separated pre-tillite sill generations.

\section{Post Lower Cambrian basic dykes \\ $72.2 \pm 9.0 \mathrm{~m}$. y. (mean of $3 \mathrm{~K} / \mathrm{Ar}$ determinations)}

GGU 114166. Medium-grained olivine dolerite from the central part of a $30 \mathrm{~m}$ thick vertical dyke belonging to a swarm of NW-SE trending, $10-50 \mathrm{~m}$ thick doleritic dykes; southern shore of Midsommersø. $82^{\circ} 12^{\prime} \mathrm{N}, 33^{\circ} 03^{\prime} \mathrm{W}$.

Mineralogy: Weakly saussuritised plagioclase, partly iddingsitised olivine, titaniferous augite, Fe-Ti oxides and a very fine-grained chloritic matrix.

This result is interpreted as a good minimum age for the intrusion of the dyke. The date corresponds to an Upper Cretaceous age on the Phanerozoic timescale. 
Regional significance of the age determinations

The unfolded sandstones in southern Peary Land with their content of pre-tillite basic sills and dykes can be correlated with similar rocks in the Danmark Fjord region. Here they are described as the "Norsemandal sandstone" which contains numerous basic intrusions (Adam \& Cowie, 1953, pp. 9-10). The sedimentary rocks can be correlated further to the east with a similar sequence in Kronprins Christian Land, from where they were first described as belonging to the "Thule Formation" (Fränkl, 1954, p. 34; 1955, p. 14). Later however Haller (1961, p. 156; Haller \& Kulp, 1962, p. 26) referred to them as the "upper part" of the Thulean beds and more recently they have been designated the "Upper Thule Group" (Haller, in press). In these folded arenaceous beds these occur characteristically as an older pre-orogenic and a younger post-orogenic set of basic sills and dykes.

In the Kronprins Christian Land region the arenaceous sediments were deposited in a geosynclinal environment and represent the youngest known sediments in the geosyncline (Haller, 1961, p. 156). After their deposition they were invaded by the first generation of basic intrusions and later the rocks in the geosynclinal tract were folded and metamorphosed by the subsequent Carolinidian orogeny, whereas the rocks in the foreland area to the north-west (Danmark Fjord and southern Peary Land regions) were left unfolded.

The final stage of the Carolinidian orogeny in Kronprins Christian Land is characterised by faulting in connection with which a younger group of post-orogenic basic dykes was intruded into the folded strata (Haller, in press). The older intrusions in the geosynclinal tract occur mainly as sills whereas the younger generation generally was intruded in the form of dykes (Haller, in press, plate 12). This indicates that a correlation of the pre-orogenic sills in the folded region with the sills in southern Peary Land is the most likely, but it is not proved. The geological setting of the two groups of basic intrusions indicates that both were formed in relation to the development of the Carolinidian fold belt.

Assuming that the correlation between the dykes of southern Peary Land and Kronprins Christian Land is correct the following conclusions can be drawn with respect to the formation of the Carolinidian geosyncline:

1) The Precambrian sandstones in southern Peary Land and the corresponding upper part of the deposits in the Carolinidian geosyncline were deposited prior to $988 \mathrm{~m}$. y. ago. The final stage of known deposition in the Carolinidian geosyncline must therefore have been reached approx. $1000 \mathrm{~m}$. y. ago or earlier.

2) If it is further assumed that no significant Caledonian updating has affected the dated dykes, the following conclusions can be drawn with respect to the formation of the Carolinidian orogeny:

a) If the dated discordant sills in southern Peary Land correspond to the Carolinidian folded sills and dykes in Kronprins Christian Land - which is considered likely the age $1000 \mathrm{~m}$. y. indicates an approximate maximum value for whichever thermal event in the Carolinidian orogeny is responsible for the slight alteration in the sill. 
b) If the dated discordant sills correspond to the dykes that were emplaced after folding in the final stage of the Carolinidian orogeny - which is less likely - the age of $1000 \mathrm{~m}$. $y$. indicates approximately the termination of the Carolinidian orogeny.

c) If the discordant sill which gave an age of $988 \mathrm{~m}$. y. corresponds to a pre-orogenic type of intrusion and the sill which gave an age of $799 \mathrm{~m}$. y. corresponds to a post-orogenic intrusion, the events caused by the Carolinidian orogeny should have taken place some time in the interval between these dates.

In all three cases, $a, b$ and $c$, the Carolinidian orogeny is indirectly indicated as belonging to the major orogenic epoch which yields radiometric ages mostly in the 1000-800 m. y. range (Grenville, Sveconorwegian).

If partial Caledonian updating of the dated rocks has taken place the age of the Carolinidian orogeny could be more than $1000 \mathrm{~m}$. y., but this is less likely.

\section{References}

Adams, P. J. \& Cowie, J. W. 1953: A geological reconnaissance of the region around the inner part of Danmarks Fjord, Northeast Greenland. Meddr Gronland 111, 7.

Fränkl. E. 1954: Vorläufige Mitteilung über die Geologie von Kronprins Christians Land. Meddr Gronland 116, 2.

Fränkl, E. 1955: Weitere Beiträge zur Geologie von Kronprins Christians Land (NE-Grönland, zwischen $80^{\circ}$ und $80^{\circ} 30^{\prime}$ N). Meddr Gronland 103, 7.

Haller, J. 1961: The Carolinides: an orogenic belt of late Precambrian age in Northeast Greenland. In Raasch, G. O. (editor) Geology of the Arctic 1, 155-159. Toronto U. P.

Haller, J. in press: Tectonic map of East Greenland (1:500 000). Meddr Gronland 171, 5.

Haller, J. \& Kulp, J. L. 1962: Absolute age determinations in East Greenland. Meddr Grønland 171, 1.

Jepsen, H. F. 1969 : Preliminary report on the stratigraphy of the Precambrian and Eocambrian sediments in the Jørgen Brønlund Fjord-Midsommersø area, southern Peary Land. Rapp. Gronlands geol. Unders. 19. 11-14.

Troelsen, J. C. 1949: Contributions to the geology of the area round Jørgen Brønlunds Fjord, Peary Land, North Greenland. Meddr Gronland 149, 2.

Troelsen, J. C. 1956: The Cambrian of North Greenland and Ellesmere Island. 20 Congr. geol. Intern. México, 1956, Symp. 3, 1. 71-90. 